\title{
The Effect of Leadership and Implementation of Licensing Policy on Service Satisfaction for Building Licenses in Bandung City, West Java Province (Study at the Investment Office and One Door Integrated Service)
}

\author{
Anwar Rosshad \\ Institut Pemerintahan Dalam Negeri, Jatinangor, Indonesia \\ Email: rosshadanwar@gmail.com
}

\begin{abstract}
:
The satisfaction of the service of the Building Permit (BP) which is the government's obligation in realizing the order to maintain the order of people's lives in a calm, peaceful and peaceful manner is an indicator of good governance. In addition, BP service is a mandatory government affair according to Law No. 23 of 2014. The purpose of this research is to analyze and determine the influence of leadership and licensing policy implementation on BP service satisfaction in Bandung City, and to find a new concepts/models of service satisfaction. The research method used is quantitative with a total sample of 248 respondents from a total population of 682 people. In data analysis, Structure Equation Model is used by processing the data collected through questionnaire data. The results of this study, which were obtained from path analysis and t-value, the effect of causality between Leadership was 0.32 (5.01) and Licensing Policy Implementation was 0.72 (9.47) on BP Service Satisfaction, all of the results were "positive and significant". The findings of this research are the Model of Emotional Service Satisfaction (MESS) which is determined by three factors, namely change-oriented leadership behavior, bureaucratic structure, and human resources. The conclusion of the research is that BP service satisfaction is in good category, all three hypotheses are accepted, and the causality relationship is positive and significant. So that new models and concepts are obtained in the field of public service satisfaction.
\end{abstract}

\section{Keywords:}

leadership; public policy implementation; service satisfaction; model of emotional service satisfaction

\section{Introduction}

The government in the Unitary State of the Republic of Indonesia (NKRI) has obligations that are embodied in its duties and functions in order to realize the state's goal of maintaining order in people's lives, so that every citizen can live a calm, peaceful and peaceful life. This objective, as stated in the Preamble to the 1945 Constitution in the fourth paragraph which reads, is to establish an Indonesian State Government that protects the entire Indonesian nation and all of Indonesia's bloodshed and to promote public welfare, educate the nation's life, and participate in carrying out order. world based on independence, eternal peace and social justice (Mauludi, 2018).

In order to actualize these goals, the government needs to carry out basic government functions which include the functions of services, empowerment, development and regulation. These functions are then embodied in several administrations of government affairs in the regions as mandated by Law Number 23 of 2014 concerning Regional Government. The success of implementing government affairs in the region in the form of satisfaction which is the right of the community is determined by the leadership in applying it. Reform of 
centralized governance patterns and less sensitive to economic, political, socio-cultural developments must be improved and directed in line with the demands of the community, in this case the people of Bandung City who hope to guarantee the interests of excellent service to the community without discrimination, introduce community control, legal certainty, order, human rights, democracy and accountability.

The demands of the community's demands can only be realized if good governance can be achieved, which is defined by Haris (2005) as a process that relates to and allows the use of state power in the economic, political and administrative fields in a skillful and effective manner by maintaining good relations. synergistic and constructive between the Government, the Private Sector and the community in carrying out their respective functions regarding State or Government affairs at every level, in this case the Bandung City Government (Kurnianingsih, 2015).

Law Number 25 of 2009 concerning Public Services explains that public services are activities or series of activities in the context of fulfilling service needs in accordance with laws and regulations, for every citizen and resident of goods, services, or administrative services provided by service providers. public. This is in line with the implementation of regional autonomy to improve public services organized by the Government, by implementing an excellent service system with a one-stop service pattern often referred to as One Stop Integrated Services (PTSP).

In order for the implementation of PTSP to be effective, Minister of Home Affairs Regulation Number 138 of 2017 was issued regarding the Implementation of Regional One Stop Services. PTSP referred to in Article 1 paragraph (4) is an integrated service in a single process starting from the application stage to the stage of completing the service product through one door. The essence of this regulation in Article 2 is to provide guidelines in the implementation of Regional PTSP in order to improve service quality, realize legal protection and certainty for the community, provide wider access to the community to obtain excellent service, and increase ease of doing business and regional competitiveness. The Ministerial Regulation mandates the implementation of PTSP to make service announcements, service standards and service management.

One Stop Integrated Service (PTSP) in accordance with Article 1 (1) Presidential Regulation Number 97 of 2014 is an integrated service in a single process starting from the application stage to the stage of completion of service products through one door. Licensing in accordance with Article 1 (5) of the Presidential Regulation, is all forms of approval issued by the government and regional governments that have the authority in accordance with the provisions of laws and regulations. The objectives of PTSP as referred to in Article 2 of the Presidential Regulation above are: 1) to provide legal protection and certainty to the public; 2) shorten the service process; 3) realizing a service process that is fast, easy, cheap, transparent, certain, and affordable; and 4) bring and provide wider services to the community. In order to realize these service objectives, PTSP in providing services must be based on the principles, namely: integration; economical; coordination; delegation or delegation of authority; accountability; and accessibility (Suryadharma et al., 2016).

One of the types of PTSP services is the Building Permit (IMB). IMB is one type of service that has received government attention with the issuance of Minister of Public Works and Public Housing (PermenPUPR) Number 19/PRT/M/2018. Article 1 paragraph (2) of the Permenpupr explains that what is meant by IMB is a permit granted by the regional government, except for special function buildings by the government to building owners to 
build new, change, expand, reduce, and or maintain buildings in accordance with applicable administrative and technical requirements.

Based on the principle of service as stipulated in the Decree of the Minister of Empowerment of State Apparatus Number: KEP/25/M.PAN/2/2004 concerning General Guidelines for Compiling the Community Satisfaction Index of the Service Unit of Government Agencies which explains the Community Satisfaction Index is data and information on the level of community satisfaction that obtained from the results of quantitative measurements of public opinion in obtaining services from the apparatus of public service providers by comparing expectations and needs.

One of the big challenges faced by the government, especially local governments, is how to display professional apparatus, have a high work ethic, competitive advantage, and the ability to adhere to bureaucratic ethics in carrying out their duties and functions. People in the regions want government officials in carrying out their duties to work optimally which ultimately can provide the best service for the community. To be able to carry out good governance, professional government officials are required, this is a prerequisite in improving the quality of implementation and the quality of services that will be provided to the community (Salmaniah Siregar, 2016).

The expectations of the community as service consumers want fair and equitable services. This is the main task of the government which is essentially to improve the welfare of the community. One of the activities to improve public services is to develop a Community Satisfaction Index as a benchmark for optimizing the performance of public services by the government to the community. Service satisfaction of Building Permits (IMB) as the focus of research and the Bandung City Investment and One Stop Integrated Service (DPMPTSP) as the research locus. Bandung City DPMPTSP is a Regional Apparatus Work Unit (SKPD) as an integrated licensing service provider for the City of Bandung.

In addition, DPMPTSP is required to be able to provide licensing services that are fast, accurate, at a cost according to the provisions, in a transparent manner to the public. This is reflected in the Vision, Mission and Main Duties and functions of the Bandung City Government DPMPTSP. PTSP in the activity of providing licensing services that have been delegated authority from the Mayor of Bandung whose management process starts from the stage of applying for permits, paying retribution, until the issuance of documents which are carried out in one place. The Regional Government gives the mandate and authority to regulate and manage government affairs on their own according to the principle of autonomy and the task of assistance to the regions is directed at accelerating the realization of community welfare through government functions, including improving services, empowerment and community participation (Sanurdi, 2020).

So based on the background described above, the researcher can formulate the focus of the problem on how much influence Leadership has on Service Satisfaction of Building Permits (IMB) in the City of Bandung and how much influence the Implementation of Licensing Policy has on Service Satisfaction of Building Permits (IMB) in the City Bandung, besides that it is a phenomenon of licensing service implementation that does not stand alone, but there are a number of variables that affect the satisfaction of licensing services in the city of Bandung. A number of variables in question can be identified from the internal environment and external environment at the DMPTSP Bandung City, West Java Province. 


\section{Research Methods}

This type of research uses a quantitative approach, while the reason the researcher uses a quantitative analysis approach is to determine the magnitude of the influence of Leadership and Licensing Policy Implementation on IMB Service Satisfaction. Then quantitative analysis is carried out using the SEM Analysis Method (Structural Equation Models Analysis), which is meant by quantitative itself is an approach method for measuring data and generalizing through samples to the population stage, in addition quantitative also uses statistical tools and data analysis if all data has been successfully collected. The data collection technique in this study used primary data and secondary data, while for the location and schedule the research was carried out within the one-stop investment and service department of Bandung City, West Java Province (Suliyanto, 2017).

\section{Result and Discussion}

\subsection{Results of Testing the Effect of Leadership on Service Satisfaction IMB}

Based on the results of research measurements as stated in this research method, quantitative data analysis using Structural Equation Model (SEM) was used. The results of SEM analysis with closed questionnaires are divided into 3, namely: Recapitulation of Overall Model Fit Test Results (Overall Model Fit), Structural Model Fit Measurement Results (Structural Model Fit), and Hypothesis Testing. The result of the overall fit of the model that serves to show the degree of compatibility between the data and the model. Then the results of the Structural Model Measurement and Hypothesis Testing which serves to show the significance and magnitude of the effect of exogenous latent variables on endogenous latent variables. The results of the SEM analysis are as follows, this study uses Structural Equation Modeling (SEM) with the LISREL program, where this method is used to test the model of the independent variable and the dependent variable together. The independent variables include Leadership and Licensing Policy Implementation and the dependent variable is IMB Service Satisfaction. The results of the direct measurement model of all latent variables and indicators using the Confirmatory Factor Analysis (CFA) model obtained a path diagram that has been standardized as follows:

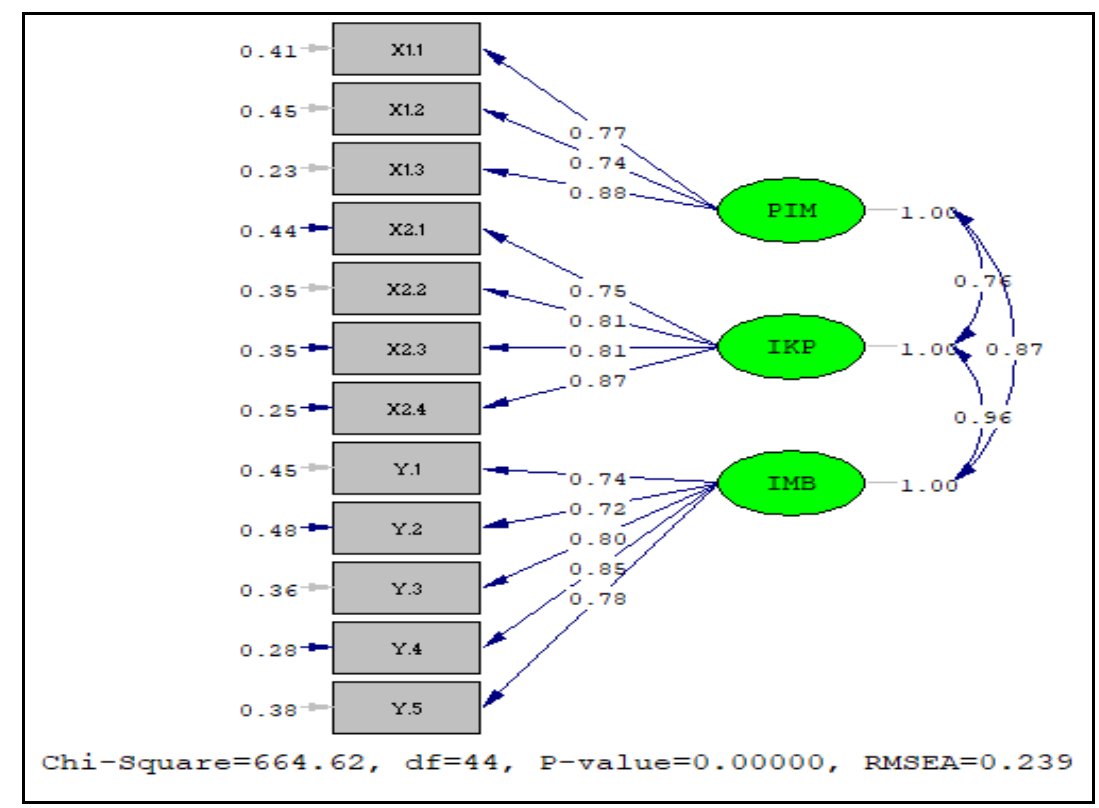

Source: Lisrel output processed by researchers, 2021

Figure 1. Path Diagram of Latent Variables and Observed Variables (Standardized Solution) 
Then based on the results of structural equation testing the influence of Leadership and Licensing Policy Implementation on IMB Service Satisfaction, further discussion is carried out on the results of the structural equation test, the results of measuring IMB service satisfaction variables, and recapitulation of structural testing and hypothesis testing. Based on the three results of testing the structural equation of the influence of Leadership and Implementation of Licensing Policy on IMB Service Satisfaction which has been carried out partially or simultaneously, the results of the determinant coefficient (R-Square) are shown in the following table:

Table 1. Determinant Coefficient Recapitulation (R-Square) Influence of Leadership and Implementation of Licensing Policy Against IMB Service Satisfaction

\begin{tabular}{|c|c|c|c|c|c|}
\hline Structure & Technique & Path & $\begin{array}{l}\text { T-Value } \\
>1,96\end{array}$ & Decision & $\begin{array}{c}\text { R- } \\
\text { Square }\end{array}$ \\
\hline 1 & 2 & 3 & 4 & 5 & 6 \\
\hline $\begin{array}{l}\text { The Influence of } \\
\text { Leadership (X1) on } \\
\text { IMB Service } \\
\text { Satisfaction (Y) }\end{array}$ & Partial & 0,90 & 11,39 & significant & 0,81 \\
\hline $\begin{array}{l}\text { The Effect of } \\
\text { Licensing Policy } \\
\text { Implementation (X2) } \\
\text { on IMB Service } \\
\text { Satisfaction (Y) }\end{array}$ & Partial & 0,95 & 12,01 & significant & 0,90 \\
\hline 1 & 2 & 3 & 4 & 5 & 6 \\
\hline $\begin{array}{l}\text { The Influence of } \\
\text { Leadership (X1) on } \\
\text { IMB Service } \\
\text { Satisfaction (Y) }\end{array}$ & simultaneous & 0,32 & 5,01 & significant & \\
\hline $\begin{array}{l}\text { The Effect of } \\
\text { Licensing Policy } \\
\text { Implementation (X2) } \\
\text { on IMB Service } \\
\text { Satisfaction (Y) }\end{array}$ & simultaneous & 0,72 & 9,47 & significant & 0,97 \\
\hline
\end{tabular}

Source: Lisrel output processed by researchers, 2021

Based on the table above, it shows that the Determinant Coefficient (R-Square), namely, the influence of Leadership on IMB Service Satisfaction partially is 0.90 or $90 \%$; 2) the effect of Licensing Policy Implementation on IMB Service Satisfaction partially is 0.95 or 95\%; and 3) the influence of Leadership and Licensing Policy Implementation on IMB Service Satisfaction simultaneously is 0.97 or $97 \%$. The results of testing the hypothesis in the table, it can be seen that the Effect of Leadership on IMB Service Satisfaction obtained a t-value of 11.39 (with a 90\% confidence level) and as the required cut of value of 1.96 (t-value $\square$ 1, 96), it shows that Leadership has a positive and significant effect on IMB Service Satisfaction. The magnitude of the influence is seen from the measurement results of the path coefficient of 0.90. The magnitude of the path indicates that the path coefficient has a strong (significant) influence and a significant causal relationship exists between Leadership and IMB Service Satisfaction organized by the Bandung City Investment and One Stop Integrated Service Office. Furthermore, the results of the measurement model for the exogenous leadership latent variable are presented in the table below: 
Table 2. Estimating Coefficient of Validity and Significance of Measurement Model Leadership Exogenous Latent Variables

\begin{tabular}{|l|c|c|c|c|}
\hline Dimensions/Factor & Loading & t-value & cut-off value & Decision \\
\hline $\begin{array}{l}\text { Task Oriented } \\
\text { Leadership Behavior } \\
\text { (X1.1) }\end{array}$ & 0,68 & 11,59 & 1,96 & Valid and significant \\
\hline $\begin{array}{l}\text { Relationship } \\
\text { Oriented Leadership } \\
\text { Behavior (X1.2) }\end{array}$ & 0,72 & 12,30 & 1,96 & Valid and significant \\
\hline $\begin{array}{l}\text { Change Oriented } \\
\text { Leadership Behavior } \\
(X 1.3)\end{array}$ & 0,79 & 14,52 & 1,96 & Valid and significant \\
\hline
\end{tabular}

Source: Lisrel output processed by researchers, 2021

The results of the measurement model in the table show that the loading factor value of each has a strong correlation to the construct of the exogenous latent variable of leadership. Based on the results of the overall examination, the weights of task-oriented leadership behavior factors, relationship-oriented leadership behavior factors, and change-oriented leadership behavior factors revealed that all factors gave significant loading factors to the latent variable exogenous Leadership. This significance is obtained from the value of loading factors for each dimension greater than 0.50. Thus, the factors included in the exogenous latent variable of Leadership have a statistically significant relationship to the construct and the manifest variables that make up the weight of each factor can be declared valid. The recapitulation of the results of the loading factors for the exogenous latent variable of Leadership in the table shows that Change Oriented Leadership Behavior (0.79) is the most dominant (weighted) factor in the process of forming the influence of Leadership on IMB Service Satisfaction organized by the Investment and Integrated Services Agency. One Door Bandung City (Sari et al., 2014).

Thus, Change Oriented Leadership Behavior is a series of factors that determine the effective support of the Leadership process and is one of the factors that determine IMB Service Satisfaction. Change-Oriented Leadership Behavior Factors have indicators, namely: (1) Paradigm change strategy, (2) Procedure adjustment, (3) Adjustment of service type, and (4) Commitment. Based on the results of the structural model measurement and hypothesis testing, as shown in the figure, it shows that the three dimensions of the Leadership study include task-oriented, relationship-oriented, and change-oriented leadership behaviors that contribute to the process of forming the magnitude of the influence on IMB Service Satisfaction organized by the Investment and Service Office. One Stop Bandung City. The magnitude of the contribution in the process of forming an influence on IMB Service Satisfaction is shown by five dimensions which include dimensions, namely: (1) product quality; (2) Price; (3) service quality; (4) emotional factors; and (5) costs.

Departing from the results of the measurement of the structural equation model, it shows that the leadership theory which is used as the theoretical basis for the preparation of the operational concept of exogenous latent variables is suitable for revealing and discussing leadership problems, and so is the theory of public service satisfaction which is used as the theoretical basis for the preparation of operational concepts of endogenous latent variables is suitable to reveal and discusses the problem of satisfaction with the IMB service. Thus, the match can be concluded that the preparation of the research concept and hypothesis testing has been based on the choice of a suitable theory to reveal and discuss the problems that are the object of research (HENDRAWATI, 2012). 
The results of hypothesis testing as in the table above show that the magnitude of the influence between Leadership and Service Satisfaction of IMB organized by the Bandung City One Stop Integrated Service and Investment Service has a significant causal relationship, meaning that if Leadership is increased or increased, then the increase is stimulant. followed by an increase in IMB Service Satisfaction. Thus, it can be stated that leadership is one of the factors that determine satisfaction with IMB services organized by the Bandung City Investment and One Stop Integrated Service Office.

Improvement of IMB Service Satisfaction organized by the Bandung City Investment and One Stop Integrated Service Office by increasing Leadership. Based on theoretical and research results, leadership improvement can be done by improving through its dimensions which include 1) implementation of task-oriented leadership behavior in IMB service satisfaction; 2) improve the implementation of relationship-oriented leadership behavior in IMB service satisfaction; and 3) improve the implementation of change-oriented leadership behavior in IMB service satisfaction. Then to improve the implementation of task-oriented leadership behavior in IMB service satisfaction includes task completion, resource efficiency, regularity of task execution and officer reliability. Improvement of relationship-oriented leadership behavior in IMB service satisfaction includes indicators of officer relations, officer assistance, officer cooperation, and officer achievement results. The improvement of changeoriented leadership behavior in IMB service satisfaction includes a paradigm shift strategy, procedure adjustment, service type adjustment, and leader commitment.

The increase in the indicators of the Leadership variable will stimulantly be followed by an increase in IMB Service Satisfaction through the indicators included in dimensions 1) product quality; 2) price; 3) service quality; 4) emotional factors; and 5) costs. Based on the results of the measurement model for the exogenous leadership latent variable in the previous table, it shows that the overall weight of task-oriented leadership behavior factors, relationship-oriented leadership behavior factor weights, and change-oriented leadership behavior factor weights have given loading factors a higher cut-off value (0.0). 50) which is categorized as significant on the exogenous latent variable of Leadership. This significance is known from the t-Values value which is greater than the cut-off Value (1.96). Thus, the factors included in the exogenous latent variable of Leadership have a statistically significant relationship to the construct and the manifest variables can be declared valid. Thus, Change Oriented Leadership Behavior is a series of factors that determine the effective support of the Leadership process and is one of the factors that determine IMB Service Satisfaction. ChangeOriented Leadership Behavior Factors have indicators, namely: 1) Strategy for changing the paradigm of IMB service satisfaction; 2) Adjustment of IMB service satisfaction procedures; 3) Adjustment of the type of service satisfaction of IMB services; and 4) IMB service satisfaction leader commitment (Rohiatna, 2020).

\subsection{Results of Testing the Effect of Licensing Policy Implementation on IMB Service Satisfaction}

The results of hypothesis testing in the table, it can be seen that the Effect of Licensing Policy Implementation on IMB Service Satisfaction obtained a t-value of 12.01 (with a 95\% confidence level) and as a cut of value required of 1.96 (t-value $\square$ 1.96), it shows that the implementation of the Licensing Policy has a positive and significant effect on IMB Service Satisfaction. The magnitude of the influence is seen from the measurement results of the path coefficient of 0.95 , which is greater than the cut of value $(0.50)$. That is, the magnitude of the path indicates that the path coefficient can be said to be strong (significant) and a significant causal relationship exists between the implementation of the Licensing Policy and the establishment of a meaningful causal relationship organized by the Bandung City 
Investment and One Stop Integrated Service Office. Then the results of the measurement model for the exogenous latent variable of Licensing Policy Implementation are as follows:

Table 3. Estimating Coefficient of Validity and Significance of Measurement Model Exogenous Latent Variables Implementation of Licensing Policy

\begin{tabular}{|l|c|c|c|c|}
\hline Dimensions/Factor & Loading & t-value & cut-off value & Decision \\
\hline $\begin{array}{l}\text { Communication } \\
\text { (X2.1) }\end{array}$ & 0,76 & 13,54 & 1,96 & Valid and significant \\
\hline Resource (X2.2) & 0,80 & 14,88 & 1,96 & Valid and significant \\
\hline $\begin{array}{l}\text { Attitude Disposition } \\
\text { (X2.3) }\end{array}$ & 0,80 & 14,87 & 1,96 & Valid and significant \\
\hline $\begin{array}{l}\text { Bureaucratic } \\
\text { Structure (X2.4) }\end{array}$ & 0,86 & 16,30 & 1,96 & Valid and significant \\
\hline
\end{tabular}

Source: Lisrel output processed by researchers, 2021

The results of the measurement model in the table show that the loading Factors values of each have a strong correlation to the construct of the exogenous latent variable of Licensing Policy Implementation. Based on the results of the overall examination of the weight of the communication factor, the weight of the resource factor, the weight of the attitude disposition factor and the weight of the bureaucratic structure factor, it was revealed that all factors had given significant loading factors to the exogenous latent variable of Licensing Policy Implementation. This significance is obtained from the t-Values value of each dimension which is greater than the cut-off Value (1.96). Thus, the factors included in the exogenous latent variable of Licensing Policy Implementation have a statistically significant relationship to the construct and the manifest variables that make up the weight of each factor can be declared valid (Dewi, 2016).

The recapitulation of the results of the loading factors for the exogenous latent variables of Policy Implementation in the table, shows that the bureaucratic structure is the most dominant (weighted) factor in the process of forming the influence of Licensing Policy Implementation on IMB Service Satisfaction organized by the Bandung City Investment and One Stop Integrated Service Office. . Thus, the Bureaucratic Structure is a set of factors that determine in supporting the process of implementing the Licensing Policy effectively and is one of the factors that determine IMB Service Satisfaction. Bureaucratic Structure Factors have indicators, namely: 1) Standard operating procedures; and 2) Coordination.

Based on the results of the structural model measurement and hypothesis testing, as shown in the figure above, it shows that the four dimensions of the study of Licensing Policy Implementation including Communication, Resources, Attitude Disposition, and Bureaucratic Structure contribute to the process of forming the magnitude of the influence on IMB Service Satisfaction organized by the Investment Office. and One Stop Service for Bandung City. The magnitude of the contribution to the process of forming an influence on IMB Service Satisfaction is indicated by five dimensions, namely: Product Quality (Y.1); Price (Y.2); Service Quality (Y.3); Emotional Factors (Y.4); and Cost (Y.5).

The magnitude of this influence indicates that between the Implementation of Licensing Policies and IMB Service Satisfaction organized by the Bandung City Investment and One Stop Integrated Services Service, a significant causal relationship exists, meaning that if the Licensing Policy Implementation is increased or increased, then the increase is stimulantly followed by increasing the satisfaction of the IMB service. Thus it can be stated that the implementation of the Licensing Policy is one of the factors that determine the 
satisfaction of the IMB Service organized by the Bandung City Investment and One Stop Integrated Service (Rohmah, 2018).

Improvement of IMB Service Satisfaction organized by the Bandung City Investment and One Stop Integrated Service Office by increasing the Implementation of Licensing Policies. Based on the theoretical and research results, the improvement in the implementation of the licensing policy can be done by improving, including 1) the implementation of the communication function in the process of implementing the licensing policy; 2) increasing policy resources in the licensing policy implementation process; 3) improve attitude disposition in the licensing policy implementation process; and 4) improve the implementation of bureaucratic structure functions in the licensing policy implementation process.

Then to improve the implementation of the communication function in the Licensing Policy Implementation process, it includes indicators of transmission of policy information submitted, consistency of policy information delivery, and clarity of policy information delivery. Improvement of policy resources in the Licensing Policy Implementation process includes indicators of staff resources, authority resources, information resources, and facility resources. Improved Disposition Attitudes of policy implementers in the Licensing Policy Implementation process include indicators of the ability of licensing officers, attitudes of licensing officers, and behavior of licensing officers. Improving the implementation of bureaucratic structure functions in the Licensing Policy Implementation process, including indicators of standard operating procedures in licensing, and coordination in licensing. By increasing the indicators of the Licensing Policy Implementation variable, it is followed by an increase in IMB Service Satisfaction through the indicators included in dimensions 1) product quality; 2) price; 3) service quality; 4) emotional factors; and 5) costs (Kharismayanti, 2017).

Based on the recapitulation of the results of the loading factors, the exogenous latent variable implementation of Licensing Policy as in table 4.14 it is known that the Bureaucratic Structure $(0.86)$ is the most weighty factor or the most dominant in the process of forming the influence of Licensing Policy Implementation on IMB Service Satisfaction organized by the Investment Office. and One Stop Service for Bandung City. Thus, the Bureaucratic Structure is a set of factors that determine in supporting the process of implementing the Licensing Policy effectively and is one of the factors that determine IMB Service Satisfaction. Bureaucratic Structure Factors have indicators, namely: 1) standard operating procedures for services; and (2) service coordination.

\subsection{Results of Testing the Effect of Leadership and Implementation of Licensing Policies on IMB Service Satisfaction}

Then the effect of Licensing Policy Implementation on IMB Service Satisfaction obtained a t-value of 9.47 (with a 95\% confidence level) and as a required cut of value of 1.96 ( $\mathrm{t}$-value $\square$ 1.96), indicating that Leadership has a positive and significant effect on IMB Service Satisfaction. The magnitude of this influence can be seen from the results of the path coefficient measurement of 0.72 . Based on the two path coefficients, it shows that the path coefficient has a strong (significant) effect and a significant causal relationship exists between Leadership and Licensing Policy Implementation and IMB Service Satisfaction organized by the Bandung City Investment and One Stop Integrated Service Office. The results of the measurement model for the exogenous latent variable of Leadership and Licensing Policy Implementation are as follows: 
Table 4. Estimating Coefficient of Validity and Significance of Measurement Model Exogenous Latent Variables Leadership and Licensing Policy Implementation

\begin{tabular}{|l|c|c|c|c|}
\hline Dimensions/Factor & Loading & t-value & cut-off value & Decision \\
\hline \multicolumn{3}{|c|}{ Leadership } \\
\hline $\begin{array}{l}\text { Task Oriented } \\
\text { Leadership Behavior } \\
\text { (X1.1) }\end{array}$ & 0,77 & 14,05 & 1,96 & Valid and significant \\
\hline $\begin{array}{l}\text { Relationship } \\
\text { Oriented Leadership } \\
\text { Behavior (X1.2) }\end{array}$ & 0,74 & 13,34 & 1,96 & Valid and significant \\
\hline $\begin{array}{l}\text { Change Oriented } \\
\text { Leadership Behavior } \\
\text { (X1.3) }\end{array}$ & 0,88 & 17,38 & 1,96 & Valid and significant \\
\hline \multicolumn{1}{|c|}{ Implementation of Licensing Policy } & 1,96 & Valid and significant \\
\hline $\begin{array}{l}\text { Communication } \\
\text { (X2.1) }\end{array}$ & 0,75 & 13,40 & 1,96 & Valid and significant \\
\hline Resources (X2.2) & 0,81 & 15,13 & 1,96 & Valid and significant \\
\hline $\begin{array}{l}\text { Attitude Disposition } \\
\text { (X2.3) }\end{array}$ & 0,81 & 15,12 & 1,96 & Valid and significant \\
\hline $\begin{array}{l}\text { Bureaucratic } \\
\text { Structure (X2.4) }\end{array}$ & 0,87 & 16,72 & & \\
\hline
\end{tabular}

Source: Lisrel output processed by researchers, 2021

The results of the measurement model in the table show that the loading Factors values of each have a strong correlation to the construct of the exogenous latent variable of Leadership and Implementation of Licensing Policies. Based on the results of the overall examination, the weights of task-oriented leadership behavior factors, relationship-oriented leadership behavior factors, and change-oriented leadership behavior factors revealed that all factors gave significant loading factors to the latent variable exogenous Leadership. While the results of the overall examination of the weight of the communication factor, the weight of the resource factor, the weight of the attitude disposition factor and the weight of the bureaucratic structure factor, it was revealed that all factors had given significant loading factors to the exogenous latent variable of Licensing Policy Implementation (Areros, 2013).

The significance is obtained from the value of loading factors for each dimension greater than 0.50. Thus, the factors included in the exogenous latent variable of Leadership and Implementation of Licensing Policy have a statistically significant simultaneous relationship to the construct and the manifest variables that make up the weight of each factor can be declared valid. Thus, Change Oriented Leadership Behavior and Bureaucratic Structure are a series of decisive factors in supporting the Leadership process and Licensing Policy Implementation effectively and are one of the factors that determine IMB Service Satisfaction. Change-Oriented Leadership Behavior Factors have indicators, namely: 1) Paradigm change strategy; 2) Adjustment of procedures; 3) Adjustment of service type; and 4) Commitment. Furthermore, the Bureaucratic Structure factor has indicators, namely: 1) Standard operating procedures; and 2) Coordination.

Based on the results of the structural model measurement and hypothesis testing, as shown in the figure, it shows that the three dimensions of the Leadership study include taskoriented, relationship-oriented, and change-oriented leadership behaviors and the four dimensions of the Licensing Policy Implementation study include Communication, Resources, 
Attitude Disposition, and Structure. The bureaucracy that contributed to the process of forming the magnitude of the influence on the satisfaction of the IMB Service organized by the Bandung City Investment and One Stop Integrated Service Office. The magnitude of the contribution in the process of forming an influence on IMB Service Satisfaction is shown by five dimensions which include dimensions, namely: (1) product quality; (2) Price; (3) service quality; (4) emotional factors; and (5) costs (Kindangen \& Pangemanan, 2018).

The results of hypothesis testing as shown in table 4 show that the magnitude of the influence between Leadership and Licensing Policy Implementation with IMB Service Satisfaction organized by the Bandung City One Stop Integrated Service and Investment Service has a significant causal relationship, meaning that if the Leadership and Implementation of Licensing Policies is improved or increases, then the increase is stimulantly followed by an increase in the satisfaction of the IMB service. Thus, it can be stated that leadership is one of the factors that determine satisfaction with IMB services organized by the Bandung City Investment and One Stop Integrated Service Office (WIBAWA, 2017).

Based on the results of the suitability test of the measurement model simultaneously the influence of Leadership and Licensing Policy Implementation on IMB Service Satisfaction organized by the Bandung City One Stop Integrated Service and Investment Service has a meaning, namely, that the theory of leadership behavior according to Yukl (2007) is used as the theoretical basis for the preparation of the operational concept of variables and the preparation of research instruments can be declared suitable to reveal and discuss the influence of Leadership on IMB Service Satisfaction organized by the Bandung City Investment and One Stop Integrated Service Office. The overall fit of the model is patterned based on the reference to the theory of leadership behavior according to Yukl (2007) which is arranged in the form of conceptual definitions, study dimensions, and indicators on the latent variable of leadership. Then it was developed according to the characteristics of the problem that became the object of research, namely the Satisfaction of the IMB Service organized by the Bandung City Investment and One Stop Integrated Service Office.

The results of research and discussion of the actual reality extracted from the IMB Service Satisfaction phenomenon organized by the Bandung City One Stop Integrated Service and Investment Service obtained a research finding is the IMB Service Satisfaction Model which touches feelings in quality service. This model is a deconcentration of research on the study of causality between the most dominant and dominant dimensions, in this context it shows that basically to increase service satisfaction, especially IMB service satisfaction, it is hoped that it will increase using a touching (emotional) approach in providing quality services by the Plantation Service. Capital and One Stop Services in Bandung City. The model of the findings of this study was extracted from the satisfaction of IMB services organized by the Bandung City Investment and One Stop Integrated Service Office (Joudeh \& Dandis, 2018).

Thus the model is given the name by the researchers is the Model of Emotional Service Satisfaction (The Model of Emotional Service Satisfaction). The model has the meaning that in increasing service satisfaction, especially IMB service satisfaction that actually occurs and events that touch feelings in quality services. The research findings model was constructed from the results of quantitative data analysis using the Structure Equation Model (SEM) and the results have been described in the table above. The results of the recapitulation of path coefficient analysis and significance can be seen the variables that have the most dominant and dominant influence between exogenous latent variables and endogenous latent variables. The most dominant and dominant level of influence is expressed by the magnitude of the path coefficient greater than 0.80 by using simultaneous or joint measurements between 
the Leadership and Licensing Policy Implementation variables on IMB Service Satisfaction organized by the Investment and Integrated Services Office. One Door Bandung City.

\section{Conclusion}

Based on the purpose of this study, there are 2 (two) conclusions, namely: (1) the relationship between the influence of the independent variable (cause) and the dependent variable (effect) on the satisfaction of the IMB service organized by the One Stop Integrated Service Investment Service, Bandung City, West Java Province, and (2) new concepts of IMB Service Satisfaction were obtained. Furthermore, the details of the conclusions are as follows, change-oriented leadership behavior that strengthens the emotional service satisfaction model. This model is actualized through a strategy of changing service paradigms, adjusting service procedures, adjusting service types, and leader commitment in service. Then the bureaucratic structure that strengthens the emotional service satisfaction model, this model is actualized by standard operating procedures (SOP), and coordination in services, then the resources that strengthen the emotional service satisfaction model. This model is actualized through service staff resources, service authority resources, service information resources and service facility resources.

\section{References}

Ali Mauludi AC, 2018, Disertasi, Pengaruh Kualitas Pelayanan dan Strategi Pemasaran Terhadap Terhadap Kepuasan dan Dampaknya Terhadap Loyalitas Nasabah (studi pada Bank Syariah Mandiri Cabang Tulungagung), Program Pascasarjana Universitas Islam Negeri Sunan Ampel Surabaya.

Areros, W. A. (2013). Aspek Interpretasi Pada Implementasi Kebijakan Pemberian Izin Mendirikan Bangunan Oleh Badan Pelayanan Perizinan Terpadu Kota Manado. Sosiohumaniora, 15(3), 312-318.

Dewi, M. (2016). Implementasi Kebijakan Iup2t, Iupp Dan Iutm Bidang Pelayanan Perizinan Terhadap Kualitas Pelayanan Di Badan Penanaman Modal Dan Pelayanan Perizinan Terpadu (Bpmppt) Kota Banjar (Doctoral dissertation, UNPAS).

Fitri Kurnianingsih, 2015, Desertasi, Dampak Implementasi Kebijakan dan Koordinasi Terhadap Kepuasan Masyarakat di Kota Tanjungpinang Provinsi Kepulauan Riau, Program Doktor Ilmu Sosial BKU Ilmu Administrasi Publik, Fakultas Pascasarjana Universitas Pasundan Bandung.

Harmaisyarah, H., \& Hasanuddin, H. (2020). Pengaruh Kualitas Pelayanan Terhadap Kinerja Aparatur Sipil Negara Dalam Penyelenggaraan Izin Mendirikan Bangunan Pada Kantor Pelayanan Terpadu Satu Pintu Kabupaten Aceh Besar. Jurnal Ilmu Administrasi, 6(2), 70-94.

Hendrawati, R. (2012). Analisis Dampak Implementasi Kebijakan Dan Budaya Organisasi Terhadap Efektivitas Organisasi Pelayanan Perizinan Terpadu Di Kota Bekasi (Studi Peraturan Daerah Nomor 9 Tahun 2008 tentang Badan Pelayanan Perijinan Terpadu Kota Bekasi) (Doctoral dissertation, UNPAS).

I Made Adi Suryadharma, I Gede Riana, Desak Ketut Sintaasih, 2016, Desertasi (Jurnal), Pengaruh Kepemimpinan dan Kompensasi Terhadap Kepuasan Kerjaf dan Kinerja Karyawan, Studi pada PT. BPR Artha Lestari Denpasar, Fakultas Ekonomi dan Bisnis Universitas Udayana (UNUD), Bali, Indonesia. E-Jurnal Ekonomi dan Bisnis Universitas Udayana 5.2 (2016) : 335-358, ISSN : 2337-3067. 
Irawan, A. (2014). Strategi Implementasi Kebijakan Perizinan Pada Badan Penanaman Modal Dan Perizinan Terpadu Kabupaten Sumedang (Studi Tentang Perizinan Bidang IPPT, IMB, Hotel, Hiburan dan Rekreasi) (Doctoral dissertation, UNPAS).

Jamal M. M Joudeh \& Ala'O Dandis, 2018, Jurnal Penelitian, Service Qaulity, Customer Satisfaction and Loyalty in an Internet Service Provider, Marketing Departement, Business Faculty, Applied Science Private University, Amman, Jordan. International Journal of Business and Management; Vol. 13, No. 8; 2018ISSN 1833-3850 E-ISSN 1833-8119 Published by Canadian Center of Science and Education.

Kharismayanti, R. (2017). Efektivitas Organisasi Dinas Penanaman Modal Dan Perizinan Terpadu Satu Pintu Kota Bandung (Studi Pelaksanaan HAY. U Bandung pada Perizinan Trayek) (Doctoral dissertation, Perpustakaan).

Kindangen, R. R., Gosal, R., \& Pangemanan, S. (2018). Implementasi Kebijakan Pemberian Izin Mendirikan Bangunan (Imb) Oleh Badan Pelayanan Perizinan Terpadu Kota Manado. Jurnal Eksekutif, 1(1).

Lana Sari, Sampurno, Djoko Wahyono, 2014, Pengaruh Kepemipinan dan Budaya Organisasi Terhadap Kepuasan Kerja Karyawan di Yogyakarta, Jurnal Manajemen dan Pelayanan Farmasi, Fakultas Farmasi Universitas Gadjah Mada.

Mukhridal, M., \& Amin, R. M. (2016). Pelayanan Perizinan dalam Pengurusan Surat Izin Mendirikan Bangunan (Imb) di Dinas Tata Ruang dan Bangunan Kota Pekanbaru Tahun 2012-2014 (Doctoral dissertation, Riau University).

Nina Siti Salmaniah Siregar, 2016, Disertasi, Komunikasi Terapeutik Dokter dan Paramedis Terhadap Kepuasan Pasien Dalam Pelayanan Kesehatan pada Rumah Sakit Bernuansa Islami di Kota Medan, Program Pascasarjana Universitas Islam Negeri Sumatera Utara, Medan.

Paat, M., Kimbal, M., \& Kairupan, J. (2018). Efektivitas Sistem Informasi Pelayanan Perizinan Terpadu Dalam Pengurusan Izin Mendirikan Bangunan (Studi di Dinas Penanaman Modal dan Pelayanan Terpadu Satu Pintu Kota Manado). JURNAL EKSEKUTIF, $1(1)$.

Rohiatna, N. (2020). Implementasi Pelayanan Perizinan Secara Online Melalui Sistem Informasi Manajemen Pelayanan Administrasi Terpadu Kecamatan (Simpaten/Oss) Di Kecamatan Bandung Kidul Kota Bandung Provinsi Jawa Barat. Visioner: Jurnal Pemerintahan Daerah di Indonesia, 12(3), 515-538.

Rohmah, A. N. (2018). Kebijakan publik dan ekonomi politik (Studi kebijakan investasi asing dan izin mendirikan bangunan dalam pembangunan Kota Meikarta di Cikarang, Kabupaten Bekasi Tahun 2017) (Bachelor's thesis, Jakarta: Fakultas Ilmu Sosial dan Ilmu Politik UIN Syarif Hidayatullah).

Sanurdi, 2020, Disertasi, Kualitas Pelayanan dan Kepuasan: Peran Harga dan Prinsip Pembiayaan Syariah sebagai Variabel Intervening (studi Nasabah KPR iB di Lombok), Program Doktor Pengkajian Islam Konsentrasi Manajemen Perbankan dan Keuangan Syariah, Sekolah Pascasarjana Univeristas Islam Negeri Syarif Hidayatullah, Jakarta.

Suliyanto, S. E., \& MM, S. (2017). Metode Penelitian Kuantitatif.

Wibawa, R. Y. (2017). Kebijakan Badan Pelayanan Perizinan Terpadu (Bp2t) Kota Malang, Dalam Pemberian Izin Mendirikan Bangunan Mall Dinoyo City (Studi Kasus Di Badan Pelayanan Perizinan Terpadu (Bp2t) Kota Malang) Oleh: Rizky Yudha Wibawa Nim: 201210050311116 Jurusan Ilmu Pemerintahan Fakultas Ilmu Sosial Dan Ilmu Politik Universitas Muhammadiyah Malang 2017 (Doctoral dissertation, University of Muhammadiyah Malang). 